\title{
TECHNICAL AND ECONOMIC ANALYSIS OF REPLACING ARTIFICIAL LIGHTING SYSTEM TO INDUCTION OF PHOTOPERIOD EFFECT IN BEGONIA'S SEEDLINGS IN GREENHOUSE
}

\section{EDUARDO DAVID ${ }^{1}$, LUIZ ANTONIO ROSSI ${ }^{2}$, ODAIL PAGLIARDI ${ }^{3}$}

\begin{abstract}
The type of artificial light used for inducing photoperiod effect in begonia's seedlings at greenhouse has fundamental importance in the growth and development of these plants and directly reflects in the electrical energy consumption used in this production process. The objective of this research was to analyze the technical and economic feasibility of replacing the current technology of artificial lighting used by the producers (incandescent lamps), by the technology of discharge lamps with the purpose of inducing photoperiod in a greenhouse. The analysis results indicate that the discharge lamp of $32 \mathrm{~W}$ Tubular Fluorescent discharge lamp was the one that presented the lower peak demand and lower average energy consumption of $85.01 \%$ compared to incandescent filament lamp of $100 \mathrm{~W}$ that is the technology of bigger consumption and currently used by the producer.
\end{abstract}

KEYWORDS: energy efficiency, artificial lighting, rural energy, photoperiod induction.

\section{ANÁLISE TÉCNICO-ECONÔMICA DA SUBSTITUIÇÃO DO SISTEMA DE ILUMINAÇÃO ARTIFICIAL PARA A INDUÇÃO DO EFEITO DE FOTOPERÍODO NA PRODUÇÃO DE MUDAS DE BEGÔNIAS EM AMBIENTE PROTEGIDO}

RESUMO: O tipo de iluminação artificial utilizado para a indução do efeito de fotoperíodo na produção de mudas de begônias em ambiente protegido tem fundamental importância no crescimento e no desenvolvimento destas plantas e reflete diretamente no consumo de energia elétrica utilizada no processo de produção. Objetiva-se com este trabalho analisar a viabilidade técnico-econômica de substituir-se a atual tecnologia de iluminação artificial utilizada pelos produtores (lâmpadas incandescentes) pela tecnologia de lâmpadas de descarga para efeito de indução de fotoperíodo em ambiente protegido. Os resultados das análises indicam que a lâmpada de descarga Fluorescente Tubular de $32 \mathrm{~W}$ foi a que apresentou a menor demanda máxima de energia elétrica com redução média de consumo de $85,01 \%$ de energia em relação à lâmpada de filamento Incandescente de $100 \mathrm{~W}$, que é a tecnologia atualmente utilizada pelo produtor, sem indução de floração.

PALAVRAS-CHAVE: eficiência energética, energização rural, indução de fotoperíodo.

\footnotetext{
${ }^{1}$ CCA-Departamento de Engenharia Agrícola/UEM, Rod. Pr 482 - Km 45 • CEP 87.820-000 • Cidade Gaúcha - PR Fones: (44) 3675-1779/36751218; eduagrounic@yahoo.com.br.

${ }^{2}$ FEAGRI/UNICAMP, Cidade Universitária Zeferino Vaz s/n, CEP 13083-875, Campinas, SP. Fone: (19) 3521-1041, rossi@agr.unicamp.br.

${ }^{3}$ Faculdade Municipal Professor Franco Montoro, FMPFM/Mogi Guaçu, SP. Fone:(19) 3891-5303, odail.pagliardi@hotmail.com. Recebido pelo Conselho Editorial em: 5-7-2011

Aprovado pelo Conselho Editorial em: 21-3-2012
} 


\section{INTRODUCTION}

The begonias were known since the $17^{\text {th }}$ Century by the Chinese. Nowadays, there are over 800 catalogued species and thousands of hybrids. The acceptance of these tropical flowers in the domestic and foreign markets is due, mainly to its beauty, forms and differentiated colors and high durability of the floral bud (AGRONEGÓCIOS, 2007). The cultivated begonias are derived from crossings initiated in the $19^{\text {th }}$ Century, arising cultivars with many characteristics, like continuous flourishing, higher resistance to high and low temperatures and innumerous formats and flower colors (PROPAGAÇÃO DA BEGÔNIA, 2008).

Nowadays, there is the search of ways to save energy by the use of conservation practices, such as the rational use of electric energy and the utilization of new Technologies of artificial illumination that may contribute so that the producers of ornamental plants change to viable economical alternatives. Few are the studies destined to establish which artificial illumination technology of the discharge type and which actuation regime of these illumination systems guarantee the growth and the development of chrysanthemum and begonias seedlings in a protected environment with the least energy consumption.

Prior studies have proved the efficiency of the use of discharge type of lamps in replacement of incandescent filament type in these production processes (DAVID \& ROSSI, 2010).

On this study it was intended to attain energetic efficiency by modifying the artificial illumination systems, and also the economy of electric energy released on this process.

The use of illumination Technologies of the discharge type, differently from the incandescent type, reduced the energy consumption and did not cause floral induction, contributing for the rationalization of the use of electric energy on the production.

\section{MATERIAL AND METHODS}

The experiment was done in a greenhouse of $4,320 \mathrm{~m}^{2}$ and $5 \mathrm{~m}$ of height. The chosen place was a company that produces ornamental plants' seedlings for the domestic and foreign markets located in the town of Artur Nogueira, at the coordinates $22^{\circ} 34^{\prime} 23^{\prime \prime} \mathrm{S}$ and $47^{\circ} 10^{\prime} 21^{\prime \prime} \mathrm{W}$, being at 588 meters of altitude, with altitude of tropical climate, rainfalls during summer, dry during winter and average temperatures of the hottest month above $24.1^{\circ} \mathrm{C}$. The company is classified on the high voltage group A4 and base charge is Horo Sazonal Verde. The annual volumetric precipitation on the town's region is from 1,300 until 1,600 mm (PEREIRA et al., 2007).

The company produces Begonias elatior seedlings and during this experiment were cultivated three varieties: Borias, Barkos and Baladin. All are produced in seedbeds that are $1.0 \mathrm{~m}$ width and $23.5 \mathrm{~m}$ in length and cultivation period of about 2 years on cultivation tables. The varieties that were used on the experiment have respectively productivities of 1.6,1.4, and 1.1 seedlings per plant per week. The planting density was 36 seedlings per $\mathrm{m}^{2}$. The development stage of the plants was on the final quarter of the production cycle of 2 years of this culture.

Inside the greenhouse the area for the trials have $24 \mathrm{~m}$ in length and $8 \mathrm{~m}$ of width, totaling $192 \mathrm{~m}^{2}$. On this area, it was occupied 3 equal sections of $32 \mathrm{~m}^{2}$, located next to the corridor. According to figure 1, in every section was installed a different illumination technology: incandescent lamp of $100 \mathrm{~W}$, Tubular Fluorescent lamp of $32 \mathrm{~W}$ and Integrated Compact Fluorescent of $20 \mathrm{~W}$, the last two with color temperature of $2,700 \mathrm{~K}$, or yellow.

Figure 1 shows the disposition of treatments on the experiment. 


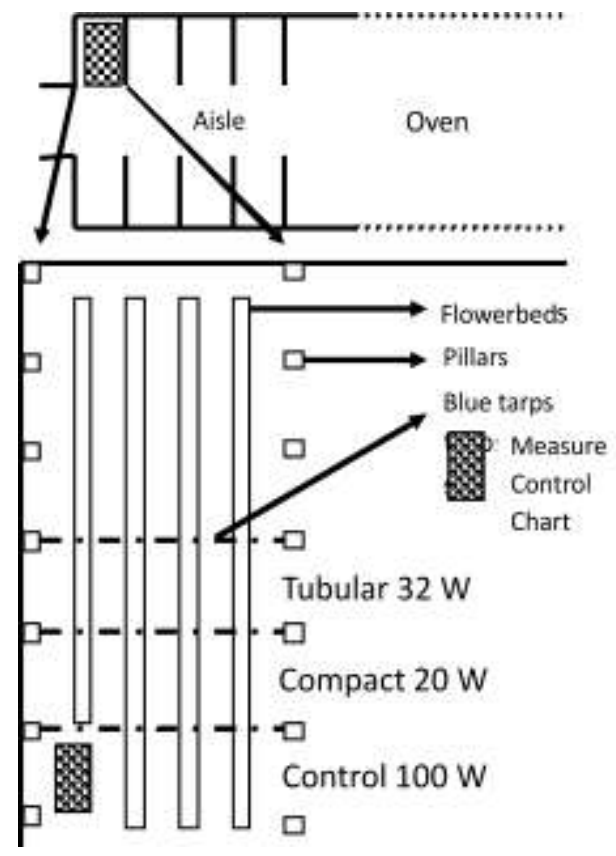

FIGURE 1. Disposition of treatments on the experiment.

\section{Parameters of electric energy usage}

The Lumen Method was used to calculate the number of luminaries by treatment, due to the need of making the light above the culture uniform (COTRIM, 2009). The table 1 shows the lifespan and the number of lamps used on the experiment.

TABLE 1. Lifespan and number of lamps used on the production process.

\begin{tabular}{lrrr}
\hline \multirow{2}{*}{ Treatment } & Lifespan & \multirow{2}{*}{ Number of lamps } \\
\cline { 2 - 3 } & Hours & Years & 0.6 \\
\hline Incandescent 100 W & 1.000 & 6.94 & 3 \\
Tubular Fluorescent 32 W & 15.000 & 3.7 & 9 \\
Compact Fluorescent 20 W & 8.000 &
\end{tabular}

Source: Philips Service of Technical Guidance. Site: www.luz.philips.com (visited in 03/05/2009)

By researching companies that commercialize electrical supply, it was obtained the installation cost (initial investment) for all types of lamps used on the experiment, which the values are on Table 2.

TABLE 2. Total installation cost for each lighting system (treatment).

\begin{tabular}{lccccc}
\hline \multirow{2}{*}{ Treatment } & \multicolumn{2}{c}{ Lamps } & \multicolumn{2}{c}{ Reactors } & \multicolumn{2}{c}{ Initial } \\
\cline { 2 - 5 } & Quantity & Cost $(\mathrm{R} \$)$ & Quantity & $\begin{array}{c}\text { Cost } \\
(\mathrm{R} \$)\end{array}$ & $\begin{array}{c}\text { Investiment } \\
(\mathrm{R} \$)\end{array}$ \\
\hline Incandescent 100 W & 7 & 1.88 & ---- & --- & 13.16 \\
Compact Fluorescent 20 W & 9 & 10.79 & ---- & ---- & 97.11 \\
Tubular Fluorescente 32 W & 3 & 23.69 & 3 & 29.16 & 158.55 \\
\hline
\end{tabular}

Source: Empresa Nortel Ltda ( 09/05/2009). For the system's monthly cost it was used the expression 1. Monthly cost by system = Monthly cost per system x Usage charge 1

\footnotetext{
${ }^{1}$ Every tubular fluorescente lamp costs $\mathrm{R} \$ 5.21$ and requires a luminaire + reactor + sockets that all together cost $\mathrm{R} \$ 47.64$. Therefore, the set of luminaire, lamp and socket costs $\mathrm{R} \$ 52.85$ each.
} 
The parameters of electrical energy collected by multivariable meters, model SAGA 2300 1387 branded ESB, were the demand $(\mathrm{kW})$, the usage $(\mathrm{kWh})$ and the factor of capacity (dimensionless). The lineation used on this experiment was in random blocks.

By the collected data of electric energy, it was compared the hourly average of capacity $(\mathrm{kW})$, electrical energy usage $(\mathrm{kWh})$, capacity factor and specific usage, between the tested lamps, using the Analysis of Variance and the Tukey Test at 5\%. The actuating regime of the artificial illumination system starts at 0:00 a.m. and ends at 06:00 a.m., non-stop, totaling 6 hours of daily usage.

\section{Analysis methods of economical feasibility}

The analysis of economical feasibility is used to identify which illumination system is more viable from an economical standpoint to replace the incandescent lamp system. Were used the traditional concepts of analysis, which are the net present value and the period for the investment return of the capital (payback) (BLANK \& TARQUIN, 2008; KOPTTKE; CASAROTTO FILHO, 2010; MAERQUES et al., 2006; HIRSCHFELD, 1992; BALARINE, 2004; NETO, 2008).

The net present value (NPV) is the most important analysis method when you desire to compare alternatives mutually exclusionary. All the costs and benefits during the studied period are brought to the present value, discounted by the attractiveness fee of the company or sector. Since it is about analyzing alternatives with different lifespans, it is used the concept of continuous replacement, calculating the lowest common multiple of the lifespans and adopting it as future cash flow. The alternative that offers the biggest net present value is considered, by this criterion, the most attractive.

A decision criteria used is the time of the investment return of the capital (payback), which allows estimating the period of return on invested capital. Just divide the cost of implantation of the investment by the benefit obtained in order to have the simple payback (not discounted). In this case, is not being considered the cost of the capital, which is the attractiveness fee of the project. When the discounted payback is considered, it is noticed the real value of money in time, obtaining a more realistic financial estimate. Although this method fails since it does not consider all the cash flow of the project, even then it was calculated.

The cash flows of replacing the basic technology (control), which is the incandescent lamp by the discharge lamp technology, were produced considering the horizon of 7 years due to it being the lifespan of a Tubular Fluorescent lamp of 32W, the biggest amongst the used technologies.

The net present value was calculated considering a yearly attractiveness fee of $15 \%$, representing the begonias' market.

\section{RESULTS AND DISCUSSION}

Table 4 shows the results of the analysis of the energy parameters to the total of lamps used on the experiment.

TABLE 4. Analysis results of energy parameters.

\begin{tabular}{lccc}
\hline \multirow{2}{*}{ Electrical variables } & \multicolumn{3}{c}{ Technologies } \\
\cline { 2 - 4 } & Tubular Fluorescent & Compact & Incandescent \\
& $32 \mathrm{~W}$ & Fluorescente 20 W & $100 \mathrm{~W}$ \\
\hline Consumption $(\mathrm{kWh})$ & $65.08 \mathrm{a}$ & $114.77 \mathrm{c}$ & $434.24 \mathrm{~b}$ \\
Demand $(\mathrm{kW})$ & $111.65 \mathrm{a}$ & $199.24 \mathrm{c}$ & $794.56 \mathrm{~b}$ \\
Capacity Fator & $0.99 \mathrm{a}$ & $0.59 \mathrm{~b}$ & $1.00 \mathrm{a}$ \\
\hline
\end{tabular}

a,b,c Averages followed by letters on the same line differ $(p>0,05)$ by the Tukey Test.

According to table 4, the Tubular Fluorescent lamps of $32 \mathrm{~W}$, Compat Fluorescents of $20 \mathrm{~W}$ and Incandescent of $100 \mathrm{~W}$ show significant differences between themselves for energy 
consumption. As demand, all the lamps showed significant differences between themselves. Only the Compact Fluorescent lamps of $20 \mathrm{~W}$ differ significantly from the other two lamps as far as Capacity Factor. Table 5 shows the perceptual reduction in energy consumption between the discharge lamps and the incandescent filament lamps (control).

TABLE 5. Percentage reduction (\%) of electric Power consumption of discharge lamps compared to the control.

\begin{tabular}{ccc}
\hline Actuation regime & Tubular Fluorescent 32 & Compact Fluorescent 20 \\
& W & W \\
\hline Continuous: 0:00 untill 6:00 a.m. & $85.01 \%$ & $73.57 \%$ \\
\hline
\end{tabular}

According to table 5, the Tubular Fluorescent lamp of $32 \mathrm{~W}$ was the one that showed the biggest percentage value in consumption reduction of energy between the discharge lamps.

Table 6 shows the monthly consumption data of the used Technologies. Still, are shown the monthly cost of energy from the different illumination systems. Since the charge group is A (high voltage), Rural Company class, classified as Green Fare, which the average electric energy consumption is of $\mathrm{R} \$ 0.133065 \mathrm{kWh}(\mathrm{CPFL}-2010$ price list), the monthly cost of the system was calculated with expression 1.

TABLE 6. Consumption (kWh/month), monthly and annual electricity cost (R\$) per treatment.

\begin{tabular}{lccc}
\hline \multirow{2}{*}{ Treatment } & $\begin{array}{c}\text { Consumption } \\
(\mathrm{kWh} / \text { month) }\end{array}$ & Monthly - R\$/month & $\begin{array}{c}\text { Annual - } \\
\text { R \$/year }\end{array}$ \\
\cline { 3 - 4 } & 135.30 & 18.00 & 216.04 \\
Incandescente 100 W & 19.62 & 2.61 & 31.33 \\
Tubular Fluorescente 32 W & 34.60 & 4.60 & 55.25 \\
Compact Fluorescente 20 W & & &
\end{tabular}

Source: Own edition

According to Tables 2 and 6, comparing only the discharge lamps, the illumination system that represents higher initial investment is the Tubular Fluorescent lamp of $32 \mathrm{~W}$ and the lowest investment is the Integrated Compact Fluorescent of $20 \mathrm{~W}$.

\section{Analysis of Economical Feasibility}

The results of the economical analysis of all the cash flows are presented on Table 7, which shows the NPV and Payback values of the artificial illuminations systems with discharge lamps when compared with the systems of incandescents (control).

TABLE 7. Evaluation methods results of replacing incandescent lamp by the high intensity discharge technology lamps.

\begin{tabular}{lcrr}
\hline \multirow{2}{*}{ Technology substitutions } & Net Present & \multicolumn{2}{c}{ Discounted Payback } \\
\cline { 3 - 4 } \multicolumn{1}{c}{ Value $(\mathrm{R} \$)$} & $\mathrm{R}$ Period & \multicolumn{2}{c}{ Years } \\
\hline Incandescente x Tubular Fluorescent 32 W & $\mathrm{R}$ \$ 727.03 & 1.6 & 0.7 \\
Incandescente x Compact Fluorescente 20 W & & 1.1 & 0.5 \\
\hline
\end{tabular}

Obs.: The values reffer to periods of 0.46 year and therefore, the net present value, which the discount fee is $15 \%$ yearly, has an equivalent fee of $6.64 \%$ by period.

Table 7 shows the economical feasibility analysis of replacing the incandescent lamps by the discharge Compact Fluorescent of $20 \mathrm{~W}$ and Tubular Fluorescent of $32 \mathrm{~W}$. The net present value for the Tubular Fluorescent lamp of $32 \mathrm{~W}$ is the highest between the two proposed alternatives ( $\mathrm{R} \$$ 
769.03) and its discoutned payback is very attractive, showing that the period of return on the initial investment is of about 9 months (equals to 1.6 period).

\section{Vegetable performance versus Spectral curve}

There was no performance alteration of the vegetables used on this experiment (presence of floral bud) due to the discharge Tubular Fluorescent lamps of $32 \mathrm{~W}$ and Compact Fluorescent of 20 W show great irradiation concentration between 600 and $660 \mathrm{~nm}$ inside the visible spectrum. According to BLANCHARD, \& RUNKLE (2009) this is the range of concentration of the more efficient irradiation in photoconversion from Pr to Psh (interconvertible phytochrome shapes), promoting a higher control in inhibition of the floral bud induction, as to the incandescent lamps.

\section{CONCLUSION}

According to the technical result of the reduction of the energy consumption, and when analyzed the traditional criteria of economical feasibility analysis, is concluded that the Incandescent lamp of $100 \mathrm{~W}$ can be replaced by the Tubular Fluorescent lamp of $32 \mathrm{~W}$ with the return on initial investment in little less than 9 months.

\section{ACKNOWLEGMENTS}

To FAEPEX/UNICAMP for the financial support to the study and to Capes by the support as a Doctorate scholarship.

\section{REFERENCES}

AGRONEGÓCIOS. Revista Fator Brasil. Disponível em: http://www.revistafator.com.br. Acesso em: 10 jul. 2007.

BALARINE, O.F.O. Tópicos de matemática financeira e engenharia econômica. Porto Alegre: EDIPUCRS, 2004. 77p.

BLANCHARD, M. G.; RUNKLE, E. S. Use of a cyclic high-pressure sodium lamp to inhibit flowering of chrysanthemum and velvet sage. Scientia Horticulturae, Amsterdam, v. 122, p. 448454, 2009.

BLANK, L.; TARQUIN, A. Engenharia econômica. 6. ed. São Paulo: MCGRAW-HILL, 2008. 780p.

COTRIM, A. M. B. Instalações elétricas. 4. ed. São Paulo: Pearson Prentice-Hall, 2003. 677p.

DAVID, E.; ROSSI, L. A. Diferentes tecnologias de iluminação artificial para produção de crisântemos. Revista Brasileira de Engenharia Agrícola e Ambiental, Campina Grande, v. 14, n. 3, p. 261-266, 2010. On line.

HIRSCHFELD, H.E. Engenharia econômica e análise de custos. São Paulo: Atlas, 1992. 461p.

PEREIRA, J.C.; VINCENZI, M.L.; LOVATO, P.E. Roland Ristow: Uma contribuição ao estudo da agricultura sustentável. Eisforia, Florianópolis, v. 1, n. 1, p. 63-97, 2007.

PROPAGAÇÃO DA BEGÔNIA. Propagação de flores de vasos. Disponível em: http://www.uesb.br/flower/propaga.html. . Acesso em: 07 Maio 2008.

KOPITTKE, H.B.; CASAROTTO FILHO, N. Análise de investimentos. 11. ed. São Paulo: Atlas, 2010. 472p.

MAERQUES, M.; HADDAD, J.; MARTINS, A.R.S. Conservação de energia: eficiência energética e instalações. Itajubá: Fundação de Pesquisa e Assessoramento à Indústria, Universidade Federal de Itajubá, 2006. 597p.

NETO, O. G. Análise de custos. Curitiba: IESDE, 2008. 176p. 